Dragan Mišetić, Ph.D.

University of Mostar, Mostar, Bosnia and Herzegovina

Ivan Kožul, Ph.D.

Šroki Brijeg, Bosnia and Herzegovina

ivan.kozul@pskola.com

Marko Tomljanović, Ph.D.

University of Rijeka, Faculty of Economics, Rijeka, Croatia marko.tomljanovic@efri.hr

\title{
INFLUENCE OF THE REMAINS OF TOTALITARIAN PRACTICE ON THE REPRESSIVE STATE INSTITUTIONS WITH ECONOMIC CONSEQUENCES
}

\begin{abstract}
Transition represents a comprehensive process of structural changes and transition "from socialism to capitalism", i.e., the return to the market economy and the civil democracy. The transition process includes changes in all segments of society, especially in the reform of the political system. As a worldwide process it has begun in the '90s of the last century and it is still present in Bosnia and Herzegovina. The transition processes include a wide range of social and political changes, which are particularly obvious in the case of Bosnia and Herzegovina. In fact, not caring for the transition, for the need to change legislative framework in the first place, as well as existing institutions, various political options limitand restrain changes in social awareness. That all lead to the strengthening of the influence of particular interest groups, which ultimately prevent the completion of structural reforms, which have economic consequences for the whole country. In this context, the repressive state institutions without a clear vision and goal and without respect for the law and its own acts, perform activities associated with the various political options, while they have no responsibility for damage caused by such acts, both, individually to persons and to the community in general.
\end{abstract}


Keywords: Bosnia and Herzegovina, transition, structural changes, jurisprudence

\section{JEL: P3}

\section{INTRODUCTION}

The process of transition implies changes in all segments of society, with particular emphasis on the reform of the political system. As a global process, transition began in the 90s of the last century, and is still present in Bosnia and Herzegovina, and represents a comprehensive process of structural change and the transition from "socialism to capitalism", i.e. transition to market economy and civil democracy.

However, without caring about the transition, or the need to change primarily legislative frameworks, as well as existing institutions, various policy options limit the implementation of changes in the social consciousness, which leads to the strengthening of the influence of certain interest groups, ultimately preventing the completion of structural reforms, which at the end has negative economic consequences for the whole country.

In this context, the repressive institutions of the state without a clear vision and purpose, and without respecting the laws and their own acts, carry out actions under the influence of various political options and have no liability for the damage caused by such actions, both individually to persons and to the social community as a whole.

Such actions are most obvious and most presentin the engagement of county/cantonal prosecutors on investigations of the directors, board members, as well as the members of supervisory boards of private commercial companies, particularly in the context of criminal offenses prescribed by the Law of Federation of Bosnia and Herzegovina (in the context of Misuse of position and abuse of authority under Article 383 paragraph 3 in conjunction with paragraph 1 of the Criminal Code of theFederation of Bosnia and Herzegovina)

Although the Article 383 of the Criminal Code of the Federation of Bosnia and Herzegovina clearly defines misuse of position or abuse 
of authority in a manner that the official or responsible person in the Federation of Bosnia and Herzegovina by takingadvantageofhis official position or authority, exceeding the limits of his/her officialauthority or failing to perform his/her official duties, obtains forhimself/herself or for the other person some benefit, causes damage to another or seriously violates the rights of another, in practice this law article is often used by the county/cantonal prosecutor's office as an instrument of pressure on private individuals and private companiesin order to achieve certain covert interests.

a) Using examples from everyday life it is possible to determine how county/cantonal prosecutors initiate various investigations and file indictments even in companies where employees were not damaged because salaries and other benefits (hot meal, transportation, assistance, ...) were paid,

b) the social community was not damaged due to the continuous investments and renewal of equipment and facilities,

c) the state institutions were not damaged because the obligations towards all budget userswere registered and paid for

d) the shareholders were not impaired because the asset's value was increased and the business objective was achieved.

It is therefore obvious that there are certain hidden political and/or economic reasons for the repressive apparatus involvement, i.e., there is an influence of the remnants of totalitarian practices and the related political options on the repressive state institutions.

In Criminal Code of the Federation of Bosnia and Herzegovina, Article 2 (Significance of the Law Terms) defines the meaning of the term : ,the official and responsible person" according to which "an official person is elected or appointed official or other official person in the bodies of legislative, executive and judicial authorities and other bodies of the administration and administration services of the Federation, cantons, cities and municipalities which perform certain administrative, professional and other tasks within the scope of the rights and duties of the authorities which has established them;persons performing their official duty on a permanent or occasional basis in such authorities;an authorized person in a commerical companyor another legal entity who has been entrusted 
for performing public function by law or other regulationspassed on the basis of the law, and which performs a certain function within these powers; and the other person who performs a certain official functions on the basis of authority from the law or other regulation passed on the basis of the law."

Furthermore, the term „respoinsible“ is defined as: "a person in a company or another legal entitywho, in view of his / her duty or on the basis of special authority, has been entrusted with a certain circle of activities related to the application of laws or regulations passed on the basis of a law, or a general act of thecompany or other legal entity in the managementand handling of property, or relating to the management of productionor other economic activity or to the supervision of these. "

The responsible person is also considered to be an official within the meaning of paragraph 3 of this Article when it comes to actions whose perpetrator is the responsible person, and when these actions are not prescribed as a criminal offense in the provisions of the chapter of thecriminal offense against official and other responsible functions, or provisions of criminal offenses whose perpetrator is official prescribed in another chapter of this Law or Another federal or cantonal law."

It is a fact that most of the directors, board members and members of the supervisory board direct their activities and their knowledge to achieve the interests of all the participants in the business process ie to realize the interests of the company itself, shareholders, employees, creditors and general interests of the social community, and not, as in a large number of cases initiated by county / cantonal prosecutors erroneously and unjustifiably state, in order to obtain the property gain to the other or to cause damage to the other.

When considering this issue, the expert work of the federal prosecutor Slavko Lakić on the topic "Problems in prosecuting and proving the criminal offense of abuse of office or authority under Article 383 of the FBiH Criminal Code" must be taken into consideration,published on the pages of the Federation Prosecutor's Office of the Federation of Bosnia and Herzegovina.The paper analyzes the basic elements of a 
criminal offense described in Article 383 of the Criminal Code of the Federation of Bosnia and Herzegovina (formerly Article 358 of the FBiH Criminal Code),by considering key perpetrators' properties,acts of execution, consequences of acts and the like.Regardless of the analyzed and reported problems and omissions, county / cantonal prosecutors and their prosecutors continue to follow their practice.

\section{CHARACTERISTICS AND ELEMENTS OF ARTICLE 383 OF THE CRIMINAL LAW OF THE FBIH}

By analyzing the existing judicial practice, it is possible to conclude that perpetrators of criminal offenses referred to in Article 383 are official or responsible personsperforming official duties, but not in the interest and for the needs of the service which they are already doing but for another purpose or interest, most commonly in the intention of obtaining any benefit to themselves or to others in this or that way, ie to cause any damage or more serious violations of the rights of others.

Also, by analyzing existing criminal law provisions in Bosnia and Herzegovina it can be concluded that legal solutions (Criminal Code of Bosnia and Herzegovina, Criminal Code of the Federation of Bosnia and Herzegovina, Criminal Code of Brcko District) have essentially only one distinction when it comes to the criminal offense in question, and it refers to the perpetrator's property.Specifically, in relation to the said property, according to the Criminal Code of the Federation of Bosnia and Herzegovina, 1) the perpetrator may be only an official or responsible person in the $\mathrm{FBiH}$ institutions; 2) according to the Criminal Code of Brcko District the perpetrator may be only an official or responsible person in the Brcko District institutions and 3) According to the Criminal Code of Bosnia and Herzegovina, the perpetrator may be only an official or responsible person in the institutions of Bosnia and Herzegovina.

In the criminal offense of abuse of possition and authority, the property of an official or responsible person is one of the essential features of a criminal offense. Also, the federal prosecutor in his paper emphasizes that the perpetrator of this criminal offense can only be "an official person or a responsible person". Defining the term 
"official person" states that it includes a larger number of persons performing functions in various state bodies, administrative institutions and services at the Federation of Bosnia and Herzegovina level. On the other hand, the term "responsible person" encompasses a larger number of entities that have been entrusted with the law enforcement in the Federation of $\mathrm{BiH}$ in a number of commercial companiesor other legal entities. According to the Federal Prosecutor, here are the powers related to the use of the housing fund, labor relations, health and social security, i.e. all the subjects to which the public authority has been transferred.

It should also be taken into consideration that the transfer or delegation of public authority is one of the ways of public authority organization, in which the state delegates a part of the jurisdiction of state bodies for carring out affairs of public interestto an entity outside the system of state bodies (institution, commerical company or other legal entity). Such form of delegation arises as a consequence of the understanding that it is more efficient for certain state affairs to be carried out by non-state entities in an authoritarian manner and in the name of public authority. The accuracy of the aforementioned is also evidenced by the fact that, pursuant to Article 23 of the Statute of the Brcko District of Federation of Bosnia and Herzegovina ("Official Gazette of the Brcko District of Federation of Bosnia and Herzegovina " No. 1/00), the Assembly of the Brcko District of Federation of Bosnia and Herzegovina adopted on one of its sessions the Law on Delegation of Public Authorities.

If the Federal Prosecutor's Office takes the previous position, i.e. the opinion regarding the definition of official person and responsible person, and if the criminal law says that the act of abuse of possition and authority under Article 383 may only be performed by an official or responsible person in the institutions of the Federation of Bosnia and Herzegovina, justifiably raises the question: Why do some county /cantonal prosecutors without complying with laws and their own acts carry out actions (investigations, indictments) against persons engaged in private companies and have no responsibility for the damage caused by such conduct?! 


\section{TERMS OF RESPONSIBLE PERSON AND OFFICIAL PERSONS}

The published expert papers on the official pages of the Federal Prosecutor's Office are in line with Prof. dr. sc. Petar Novoselec work, which emphasizes that the concept of a responsible person was created in former Yugoslav law and how it should serve to equalize some persons important for the functioning of the system with the official persons. Aforementioned was particularly pronounced in criminal offenses against official duty, since not only official persons were identified as perpetrators of abuse of official status, but also other persons important for the effectiveness of the legal system, especially managers in the economy.

If such a solution, that perspectivecould be defended by the need to provide special state control over economic life (which is also questionable because even in the former system, over time, a separation of economic activity from the state, and thus "economic managers" from civil servants,was developed), for Prof. dr. sc. Novoselec, from the standpoint of today's law, that is the ultimate anachronism.

Furthermore, the responsible person in the economy is a private person regardless of the social meaning of his/hers activity and should not be equated with the official person. Novoselac adds that, in the event that the legislator in the Republic of Croatia does that, for example, when, as a perpetrator of a criminal offense of abuse of position and authority under Article 337, paragraphs 3 and 4 of the Criminal Code, in addition to the official person predicts the responsibleperson, he transforms an economic offense in the official offense. Such an attitude is in opposition even with entrepreneurial freedom, of which does not remain much if the entrepreneurs are treated as part of the state authority.

Also, in expert and scientific papers, it is pointed out that the modern criminal codes (Slovenia, Croatia, ... ..) are not acquainted with the term responsible person, and the perpetrators of economic crimes are most often labeled with the word "who". A large number of authors who deal with this area at the expert and scientific level, reffere to 
criminal offense that is still commonly addressed to directors, administration members and members of the supervisory boards as "the monster from the past that has survived the collapse of communism in whose lapit was bred".

\section{RESPONSIBILITIES OF THE MEMBERS OF COMMERCIAL COMPANY}

Persons who are engaged in various management activities, i.e. directors, administration boards membersand supervisory boards members, etc., are aware that the law stipulates that members of the management and supervisory bodies of the companies(in the earlier legal decisionsfor the joint stock companies was the administrative board, the supervisory board and the management of the company) have certain powers in terms of managing the affairs and representation as well as supervision over the management of business affairs of the commercial companies.

Existence of such powers of the members of administrative and supervisory bodies presupposes the existence of their responsibilities in the event of non-fulfillment of obligations as well as the existence of an obligation to act with particular care in the exercise of those powers. However, it should not be ignoredthat members of the administrativeand supervisory bodies of the company in the first place respond to the company itself, which is an independent legal entity in the legal trades, and also have to take into account the interests of the various participants in the one.

Regarding the observed article of the law on abuse of authority as well as for causing damage to another, it is important to state that from the legal regulations stemsthe fact that in the event of violation of obligations by the members of the administrative and supervisory bodies in the joint stock company, the shareholders themselves are allowed to file lawsuits for compensation of damages against members of the administrative and supervisory bodies. The relevant expert and scientific public has addressed this issue and stated that these lawsuits were filed on behalf of the joint-stock company, and the possible compensation for the damage will be granted in favor of the 
joint-stock company and not of individual shareholders. The prerequisite for submitting them is that there has been a direct damage to shareholders due to harmful acts of members of the administrative and supervisory bodies. Also, claims for compensation of damages can also be made by the company's creditors if they can not settle their claims from the company, and this is only true if the administrationmember or the supervisory board memberseriously violates the duty and disregards the attention of a neat and conscientious businessman.

In the context of these provisions, the question also arises: If an action suspectedly made by directors, members of the administration and / or members of the supervisory board, caused any damage, why would not one of the interested parties (shareholders) file appropriate lawsuits before competent civil courts, rather than the county / cantonal prosecutor's offices carry out investigative actions and bring indictments before the courts responsible for criminal proceedings?

Therefore, the legal regulations as well as the relevant scientific and expert documentation show that the responsibility of members of the administrative and supervisory bodies for the violation of their obligations in the conduct of business and representation of the company, as well as in overseeing the conduct of the company's business is pointed towards the company itself. Therefore, administrative and supervisory bodies are authorized to file a claim for compensation of damages and the shareholders of the company are only exceptionally competent. To clarify, it should be emphasized that in both cases the shareholders directly or indirectly submit a claim on behalf and for the account of the company, and any compensation for damages belongs to the company and not to certain shareholders who filed the lawsuit.

In relation to the foregoing, the question is: For whom do the county / cantonal prosecutors, in carrying out their actions in the case of suspicions of directors, members of the board of directors and members of the supervisory boards, seekcompensation of damages and to whom should the damage belong? 
When filing a lawsuit, there is a need to determine the justification and purpose of filing such lawsuit for the company, so the consent to filing it is provided by the general assembly of the company, the court or the special committees within the joint stock company. In this way, it is intended to prevent the abuse of the right of the shareholders for filing the lawsuit an by doing so to cause damage to the joint stock company and the normal conduct of its business. With regard to the actions they take, it is obvious that repressive institutions are not respecting the legal provisions on the abuse of certain rights and protection of the normal business cycle, but under the influence of various political and economic options use their power.

The filing of the lawsuit is usually preceded by a special audit procedure, that includes gathering facts about the possible omissions of the members of the administrative and supervisory bodies of the joint stock company, which is the basis for its filing. If all the above mentioned is defined in the laws and generally accepted in the business of companies, it is necessary to ask: Why should the county / cantonal prosecutors still allow different views and attitudes to themselves?

It is precisely due to the influence of the remnants of totalitarian practice and the related political options that the members of the administrative and supervisory bodies all work in accordance with law and business practices, that the audits show the orderliness of the conduct of the business, but that the county / cantonal prosecutor's officesstill initiate the investigation and only on the basis of its created perceptions file the indictments.

\section{BUSINESS JUDGEMENT RULE}

Although directors, administration members and members of the supervisory boards in most cases work in accordance with positive legal regulations, international accounting standards, statutes and other company documents, and in accordance with positive business practices, ie in accordance with the Law of Commerical Companiesof the Federation of Bosnia and Herzegovina, they are often the subject 
of various investigative actions and filings of indictments by county / cantonal prosecutors' offices.

The arising question is how much are the prosecution and prosecutors aware of the law on the companies and its provisions, and in particular how familiar are they with article 32, paragraph 4, which states that:"Persons referred to in paragraph (1) of this Article are performing their duties conscientiously, with care of a good businessman and in a reasonable belief that they act in the best interest of society (hereinafter: due diligence)",and with paragraph 5: "A person who acts with due diligence is not responsible for the damage caused by such an assessment for the company", when reconsidering day-to-day business decisions sometimes even in a distance of ten or more years. It also raises questions as to whether the prosecutors and members of the prosecution worked in the real sector and whether they had to make daily decisions in an uncertain and turbulent business environment? Obviously they forget that no one, not even the world's top managers, have a continuous top-notch achievements and have made all the right decisions, especially not when considering decisions made with time lag.

Reasonable beliefand due attention, as defined in the provisions of the Law of the Commericial Companies, in the light of world trends, is further more and with more details explained in the academic Jakša Barbić's paper: "Responsibility of the Commercial Companies Board Membersfor the Damage ". In the paper, it is clearly stated when and why a member of the board can be held accountable for the damage. Among other things, it is stated that the US law developed the concept of a business judgment rule by which there is no judicial control of members of the board, provided that the prerequisites of fair judgment are respected in their work. As noted by academic Barbić, the rule is also accepted in the German judicial practice, with relying on the fact that the administration/board of a joint-stock company must, in the conduct of business, be given more room for decision-making without which entrepreneurial activity can not be imagined. In the Republic of Croatia the same rule is contained in Article 252, paragraph 1 of the Commercial Companies Act, in such way that itprescribes that a member of the administration does not act contraryto the obligation to managethe company's business, if when making an entrepreneurial 
decision he can, on the basis of appropriate information, reasonably assume that he is acting for the welfare of society.

Taking into account legal provisions as well as scientific papers, it is evident that the legislation of the Federation of Bosnia and Herzegovina is in line with the legislation of developed western states andfrom these legal provisions derive the following assumptions for the application of the rules of business judgment: a) the administration must make an entrepreneurial decision, b) the administration must reasonably be expected to act for the welfare of the company; c) when making decisions, the risk must not be too high; d) the administration decides on the basis of appropriate information, e) there must be no conflict of interest, f) The administration must act in good faith.

How many of these rules by which act the directors, board members and members of the supervisory board, the county/cantonal prosecutorsin their activities of today want or can accept remains a question, and there is certainly a need for further education to raise competences and reduce the influence of external factors on their work.

If the previous assumptions for the application of the rules of business judgment are fulfilled, academic Barbic considers that it is not a violation of the obligation of a member of the board to act as aneet and conscientious businessman, thereforethere can be no saying (It can not be argued) that there is no guilt in his conduct, which is why it is not even a matter of determination/establishing, but it is determined that the obligation of the member of the administration has not been violated, which otherwise could come with guilt and without it. Furthermore, academic Barbic states that it is an irrefutable presumption that this is so, and that it is not the case of a rule that only regulates the burden of proof, but is a norm of substantive law by which a member of the board then acts in accordance with its obligations in company. 


\section{RESPONSIBILITY AREA OF THE EXECUTIVEMEMBERS OF THE COMPANY}

Laws, documents and acts of Commercial Company, standards and business practices determine that members of the administrative and supervisory bodies take care of the interests of the company itself, but also of the interests of shareholders, employees, creditors of the company and ultimately of certain general interests. Therefore, the assemblies of Commercial Company make the Statutes of the companies which determine the internal organization of the companies, the way of managing the company, the way of making general and individual acts of the company, as well as other issues related to the work and business of the company. Normally, the statute defines the bodies of administration in company, the competence of the governing bodies, and the way of decision making.

The statutes of companies define that the company is being run by the company's director or by the company'sadministration, and the following are especially performed by them:

a) organization of the work process; b) managing the business of the company and organization of the work of the company; c) representing the company; d) responding for the legality of the work of the companies; e) executing the decisions of the assembly of the company and the Management Board of the company, ie the implementation thereof; f) starting the initiatives and making suggestions for improvement of the company's business; g) deciding on establishing a working relationship with the employees of the company and terminating the employee's employment relationship, h) appointing and dismissing employees with special powers, and i) proposing to the Management Board the business plan of the company, j) preparing business reports and submitting them to the Management Board for consideration and decision making, $\mathrm{k}$ ) performing other business activities from the domain of the independent Management Boardin accordance with the Law.

The Statute of most companies as well as the Law on Commercial Companies establishes that the Management Bordorganizes work and manages business. The key word is managing so to clarify, for the purpose of identifying the concepts ofadministrating/controling, 
leadership, handling, management, it should be stated that in the practice of domestic companies/firmsisgenerally accepted to identify the concept of management with the concept of handling, and administrating/controling is considered to be one of management functions or functions of leadership.

As management is defined"as a process of working with others and through others in achieving organizational goals, with the efficient and effective use of limited resources in a changing environment," it is evident that in such circumstances the director and the members of the board have the task to carry out the activities that lead to achievement of the set goalsand the protection of the interests of all involved in business transactions, and the managers of some expert services lead, i.e.manage the activities of their/its business functions in accordance with the content of the established duties and obligations.

For further determination of the totality of the relationship and the way of working in the Commercial Company, it is necessary to state the fact that it is under the Labor Actand the company's statute, that the internal organization and systematization of the workplaces, ie the work regulationis being adopted.

Organization and systematization of workplaces is defined as a form of organizational structure and it is predominantly functionalin the Federation of Bosnia and Herzegovina, which implies that the jobs are carried out through joint expert services of companies. Generally the company is managed by the director of the company or the members of the management in accordance with the Statue powers and in the execution of the affairs are assisted by the deputies, assistants and executivesof the service for certain types of work (Commercial Affairs Department, Economic-Financial Affairs Department, General Legal and Personnel Services Department, Department of Technical Affairs).

Throughout the internal organization and systematization of jobs, all the jobs are usually described. In the following are the usual job descriptions that, to a large extent, by their execution or nonexecution, are related to the perception of acts of misuse of position or abuse of authority: 
a) The Head of the Economic-Financial Affairs Department organizes and supervises the work of the finance service, cares about the proper application of the financial regulations in the company, cares about the implementation of the financial policy of the company in accordance with the decisions and guidelines of the Supervisory Board and the legal regulations, cooperates with the director of the company in the matter of finance, manages the company's finances, uses and repays long-term, short-term and consumer loans, insures assets and persons, controls the correctness of salary calculation, cooperates with other service managers, monitors regulations in thefield of payment transactionsand takes care for their proper implementation, makes the annual holiday plan for staff within the service, makes periodic and final calculations, and other tasks assigned to him by the director of the company.

b) Financial officer in department of economic-financial affairs organizes and monitors the work of cash register, takes care of the application of the cashier's regulations, organizes and controls the booking described in the tasks of the employees in the workplaces of the accounting clerk, and supervises the correctness of the work done in the activities described under this workplace, checks the business units' deleveraging according to the methods of payment, performs, together with the Head of Service, data preparation and preparation of informations for analytics, is concerned with the correct application of the contingency plan/chart of accounts, produces monthly reports of possible disagreements for the purpose of prompt response, verifies the prepared documentation for bookingperforms other tasks as instructed by the manager or director of the company.

c) Financial clerk in department of economic-financial affairsperforms work of preparation, commissioningand controlling of accounting system operations, records data in the system and performs their bookkeeping, carries out alignment with customers and suppliers through prescribed forms and takes care about all correspondence about alignment, warns the authorities about the maturity of individual receivables and liabilities, warns the buyersaboutthe maturity of their liabilities, prepares reviews of overdue receivables that are 
written off, performs other tasks related to the said registers, aligns store's books with the bookkeeping, determines the differences in the store's inventory, takes care of the annual lists provided to him by the immediate supervisor, performs the tasks of controlling and systematical classification of the business documentation according to the analytical chart of accounts, keeps thegeneral ledger, keeps the general ledger analytics, conducts documenting and storages bank accounts statements, takes care of bookkeeping supporting documents, makes reviews of receivables that are written off by the law, provides the necessary data in the preparation of the accounting reports, monitors and takes measures for the collection and payment of receivables and liabilities from the registry, binds the business books after the end of the year and performs other tasks assigned to him by the immediate supervisor, takes care of the bookkeeping of cash register, receipt statements, entry accounts, bookkeeping of cessions and compensations, harmonization of open items of alignment of merchandise and financial bookkeeping, merchandisebookkeeping, and performs other tasks according to the instructions of the supervisors or director of the Company

d) Head of the General, Legal and Personnel Services Divisionorganizes and manages legal, personnel and general affairs,supervises the work of employees within the service, improvesthe system of normative regulation of relations in company, looks after the application of provisions of general acts, takes the initiative to amend existing and to the adoption of new general acts, prepares the materials that should serve as a basis for the drafting of general acts, provides expert assistance to bodies that prepare proposals for the drafting of general acts, that draft general acts proposals and appropriate explanations, under the authority of the director, represents the company before other bodies and organizations, submits applications for company registrationat the competent court, makes contract proposals and participates when concluding them, looks after the lawful execution of the contract,elaborates the plan for the use of annual vacations for employees within the service and others,performs other tasks in cooperation with the director of the company. 
e) Officer for legal and general affairs-participates in the work of the head of the service and assists in the execution, prepares the proposals of the contract and other acts necessary for the work of the company, according to the instructions of the manager comes in direct contacts with state administration bodies, makes submissions and letters for communication within and outside the company, prepares materials for sessions of the bodies of the company and the auxiliary bodies,drafts descision proposals for the sessions of the company's bodys, delivers invitations and materials for the sessions, drafts decisions and other acts issued by the bodies of the company,disciplinary and other commissions, and makes certain resolutions and provides preconditions for their execution, provides the necessary information material,records the data on the members of the organs of the company,their executive bodies and auxiliary bodies,collects applications for adverts and a job-search contest and answers them,contacts the social, health andretirement insurance of the employee, submits the necessary registrations and deregistrations of employees, makescontracts and decisionson the reception of employment, schedule of work and work tasks and about the termination of employment of employees,makes annual vacation decisions and keeps records on the use of the same, performs other tasks in co-operation with the head of the service.

Such or similar organization and systematization of workplaces shows the totality of relationships and relations between all business system factors, the way of internal division of labor, the organization of lower organizational units, the horizontal and vertical division of duties, rights and obligations as well as the relation of authority and responsibility.

There is also an evident division of work, grouping and linkage of affairs as well as linking of organizational units, defined by appropriate business functions, where each organizational unit performs tasks of a certain function for the whole organization.

With this or similar organization and systematization of company;a) there is a high degree of specialization and division of labor; $b$ ) there 
is a logical connection of tasks in the business functions; c) the assumptions for professional management and the unified coordination of jobs of the same function are established;d) the significance and importance of the main functions for the company as a whole is emphasized; e) the education of managers ie supervisors of running each of the business functions is facilitated; f) communication and created preconditions for control at all levels of management is provided.

The heads of expert services themselves prepare documents, participate in decision-making, compile, certify and sign the necessary reports in person, so the director or board member or supervisory bord member can not abuse the position or authority except 1) if he/she did not choose the associates himself and by doing so did the omissions, 2) if he/she has no supervision over their work, or 3) if he/she issued instructions contrary to the law and profession.

The business organization itself in more complex Commercial companies, with more members of the board and members of the supervisory board, shows that it is not possible to have direct intents (an essential element of the act) and the awareness that they use their position to gain benefit for themselves or others. Theory and practice show that in a complex functional organizational structure it is not possible to authoritatively conduct a business. Specifically,each of the key functions of the company(finances, accounting, legal and general affairs, commercial affairs, techniques and maintenance) is being held and taken care of in accordance with legal regulations, standards of conduct, job descriptions, employment contracts, by different people with appropriate knowledge and professionalqualifications, all in accordance with organizational structure and systematization of jobs.

Regarding the position of the director as a management body, the theory and practice have recently accepted the view that the director or board member or supervisory board is not responsible for the work of persons employed in the company, except when his or hers responsibility can arise only if he or she made a mistake in selection of those employees, supervision their work, or giving instructions. 
Among other things, in the court practice of the Republic of Croatia (Novoselec, 2013) it is stated that "... they are not right when they claim that the responsible person may only be the person who is registered as such in the register of the competent commercial court ...", and the federal prosecutor Lakić States states in the paper "Problems in the Prosecution and Proving of the Criminal Offense of Abuse of Position or Authority under Article 383 of the Criminal Code of the FBiH", as the term of an official or responsible person does notdetermine only the managing position of employees in the legal person, but the fact that that employeewas entrusted with certain authority or duty.

Otherwise, essential features of a criminal offense of abuse of office or authority, for which are charged directors, board members and members of the supervisory bord, will not be realized, but some other criminal offense will.

Although the Federal Prosecutor's Office points to the fact that the experience and practice in the proceedings of prosecution (county / cantonal prosecutors' offices) in the Federation of Bosnia and Herzegovina shows that there are problems in the proceedings of prosecutors when it comes to identifying the perpetrator of the criminal offense referred to in Article 383., above all in the investigation, at the phase of recognizing and determining a particular circle of people or a specific person who may have the status of official or responsible person in a specific criminal offense, the county / cantonal prosecutors have no responsibility for the damage they cause through such treatment, both individually to persons as well as to the Commercial companies and to the social community as a whole.

\section{ARTICLE 383. OF THE CRIMINAL CODE}

The fact that in the experience and practice director or a member of the board does not respond for the work of the employees in the company, shows the justification of the issues and the additional determination of the facts regarding the possibility that sometimes various informants of the criminal misdemeanors are involved in the work, as well as in the preparation and implementation of decisions 
for which county / cantonal prosecution offices suspects directors, board members, and supervisory board members. Why is it necessary to further examine the previous claim?Specifically, in order for the directors or members of the administration to commit the relevant offense of misuse of office and authority, there is a need for direct intent (dolus directus),i.e. the existence of awareness that their position is exploited, or that they do not perform a trusted duty in order to obtain benefits for themselves or others.

However, in most cases, the situation is exactly the opposite, i.e. if the repressive institutions looked at all the documentation and looked at all business events, in most cases the active role of the informants would be seen with regard to the positions they had in the namedCommercila Companies. This does not mean that in such an active role the informants have committed the described criminal offense, but merely indicate how they use,with their partial informations and documents, the repressive institutions for their hidden goals and interests.

In accordance with all of the above, and given the totality of the problem, various untruths spoken through false reports, frequent staged press statements and writings, involvement of a large number of institutions and agencies in control and investigative activities, all to avoid thescenario of the story of the wise men and the elephant: "Four wise men to whom they bound eyes, came to the elephant, and touched him. The first sage who caught the elephant's leg said: The elephant is like a thick bamboo trunk. The other sage has touched the elephant's trunk and said: The elephant is like a python. The third sage touched the elephant's stomach and concluded: The elephant is like a rock. The fourth sage caught the elephant's ear: The elphant is gentle and soft as a leaf." It is needed to be rational, substantive and comprehensive. As can be seen, because of a blindfold (lack of informations and / or manipulation of informations) over the eyes, no sage has established the true state of the subject. However, when they removed the bonds from their eyes, they saw that, regardless of wisdom, observation of only one part of the subject / problem leads to a wrong conclusion. 
Therefore, in their engagement duringprocessing and proving of the criminal offense of Abuse of Position or Authority under Article 383. of the Criminal Code of the Federation of Bosnia and Herzegovina, for which are suspected directors, members of the Board and the supervisory bord, if they wish to avoid the influence of various political and economic options, the repressive institutions, should without any doubt and with all the expertise (legally and economically), establish:

a) the place of exploitation and overcoming the position limits,

b) the manner of execution of the imputed offense

c) What is and how big is the benefit gained to the another person?,

d) who has been harmed by the subject activities, or business events?,

e) What is the connection between the status of a responsible person and the official position?,

f) What is the position and responsibility of the head of the expert services?,

g) Who and how has prepared the documents (contracts, decisions, etc.) related to the business event in question?,

h) Do the business events inquestion appear in the business books?,

i) Did the informants participate in the work and in making of the decisions in question?

\section{CONCLUSION}

Taking into account previously stated views of the scientific and expert public, and the legal provisions according to which the perpetrator of the offense referred to in Article 383 of the Criminal Code of the Federation of Bosnia and Herzegovina can only be an official or responsible person in the institutions of the Federation of Bosnia and Herzegovina, it is not clear how repressive institutions can charge directors, members of the board and members of the supervisory boards of private Commercial Company for the commission of a criminal offense referred to in the article in question, obtaining benefits or causing damage. 
An approach in which various political and economic options unjustifiablyinfluence on the repressive institutions to run various investigations and indictments on the directors, members of the board and the members of the supervisory board, primarily israising the dust, in order to find something in the dust. In today's world there is constant talk of managers, and it always again raises the question: What, or who is an ideal manager? This question can be answered without any problems, so an ideal manager can be clearly identified as the one who: a) must think entrepreneurialy, be a team player, b) is communicative, visionary, ecologically aware, c) thinks outside the framework of his country, d) is socially oriented, charismatic , e) is multicultural, intuitive, f) is customer oriented. All of this shows the characteristics of the manager as a universal genius.

If we agree to the discussion about existingof a universal genius, we would have to agree and conclude that this is a very rare occurrence. It is too rare to hope that there will be enough of them to take even a fraction of the leading positions in the modern world, let alone to engage in economic Commercial Companies operating in the Federation of Bosnia and Herzegovina. However, apparently repressive institutions and their associated political and economic options after significant time lag use weaknesses of directors, board members, and members of supervisory boards that they have not prove themselves as a universal genius in day-to-day business management and making of business decisions.

Everyone, even the repressive institutions, involved in the economic life of aregion, should know that the starting point from which the problem is to considered is not genius, but a plain man since no one else is at disposal.Nobody, not even the world's best managers hascontinuous top achievements, so it is absurd to keep insisting and observingof time-lag decisions when it is known that they were brought in good faith and with reasonable assumptions.

According to the thoughts that the entire knowledge that we have comes from experience, and that whatever we are dealing with is our perception, we can properly ask questions: What is the experience of a prosecutor when he does not distinguish basic legal and economic categories? What is the experience of the prosecutor when he does not 
know the laws which directors and the board members meet on a daily basis? What is the experience and knowledge of a prosecutor when he can not determine for a number of years who are the directors, owners, members of the management and supervisory boards of the handled companies? What is the experience and knowledge of the prosecutor if his engagement is based on incompetence?

Because of these and a whole range of other issues, it should not be allowed that the perception which the prosecution creates just because it is influenced by different political and economic options and which is not the real world but only the idea of that world, ie its mental representation, is sufficient to accept the indictments and causing damage to people but also to economic companies- Commercial Companies without any consequences for such erroneous/wrong, immoral and illegal decisions.

The prosecution's obligation is to act morally and legally, which evidently was not an example of everyday practice, as the practice shows thatthe entire series of indictments do not show the real criminal offenses but merelythe ideas and perceptions of the prosecutor's offices about these offenses. Since the idea is closely related to experience and then to knowledge, it is evident that these "acts" will only exist as long as the prosecutor perceives or until he or she acquiresthe knowledge or experientially understands all the shortcomings and errors of his/hersunjustified perception.

\section{LITERATURE}

1. Barbić, J. 2009. Odgovornost članova uprave društva kapitala za štetu, Računovodstvo, revizija i financije, No. 9, pp. 148.

2. Barbić, J. 2013. Pravo društava, Knjiga druga -Društva Kapitala, Zagreb: Organizator

3. Jurić, D. 2007. Pravo manjinskih dioničara na podnošenje tužbe u ime dioničkog društva protiv članova uprave i nadzornog odbora, Zbornik Pravnog fakulteta Sveučilišta u Rijeci, Vol. 28, No. 1, pp. 541-586

4. Lekić, S. 2013. Problemi u procesuiranju i dokazivanju krivičnog djela zloupotrebe položaja ili ovlaštenja iz člana 383 Krivičnog 
zakona $\mathrm{FbiH}$, dostupno na:

http://pravosudje.ba/vstv/faces/pdfservlet;jsessionid=34a61ab31e 7d2 6d25510252879db0efad25e774fbc6e8640fe2e48d68e 375fe0.e34Tbx yRbNiRb40Lb38TbhePa30Pe0?p id doc $=26801$

5. Matijević, D. 1999. Tyranosaurus u Kaznenom zakonu, Odvjetnik, No. 9-10, pp. 42-45

6. Novoselec, P. 2002. Zlouporaba položaja i ovlasti kao gospodarsko kazneno djelo - kritika jednog zakonodavnog promašaja, Hrvatski ljetopis za kazneno pravo i praksu, Vol. 9, No. 1, pp. 3-36.

7. Novoselec, P. 2013. Sudska praksa, Hrvatski ljetopis za kazneno pravo i praksu, Vol. 20, No. 1, pp. 268.

8. Službeni glasnik Brčko distrikta BiH, 2016., dostupno na: http://skupstinabd.ba/ba/87-obavjestenje-glasnik.html

9. Službeni glasnik BiH, 2016., dostupno na: http://www.sluzbenilist.ba/

10. Kazneni zakon Federacije Bosne i Hercegovine, 2016., dostupno na: http://www.oss.ba/dokumenti/Krivicni_zakon_FBIH.pdf

11. Zakon o gospodarskim društvima $\mathrm{FBiH}$. 2016., dostupno na: http://www.fbihvlada.gov.ba/bosanski/zakoni/2015/zakoni/12h.html

12. Zakon o radu FBiH. 2016., dostupno na: https://advokatprnjavorac.com/zakoni/Zakon-o-radu-Federacije-BiH-2016.pdf 